\title{
Anti-colon cancer and antioxidant activities of bovine skim milk fermented by selected Lactobacillus helveticus strains
}

\author{
K. R. Elfahri, ${ }^{*}$ T. Vasiljevic, ${ }^{*}$ T. Yeager, $\dagger$ and O. N. Donkor ${ }^{* 1}$ \\ ${ }^{*}$ College of Health and Biomedicine, and \\ †College of Engineering and Science, Advanced Food Systems Research Unit, Victoria University, PO Box 14428, Melbourne, Australia 8001
}

\begin{abstract}
Bioactive compounds released during milk fermentation by proteolytic cleavage of milk proteins have a role beyond their nutritional importance. This study assessed the proteolytic activity of Lactobacillus helveticus strains ASCC953, ASCC474, ASCC1188, and ASCC1315 and their ability to release bioactive compounds capable of exerting antioxidative and in vitro anticarcinogenic properties during incubation at $37^{\circ} \mathrm{C}$ in reconstituted skim milk. The performance of these strains was not affected by the $\mathrm{pH}$ decline during fermentation. Soluble extracts of fermented milk by L. helveticus 474 showed the highest free radical (1,1-diphenyl-2-picrylhydrazyl) scavenging activity at $12 \mathrm{~h}$ of fermentation, followed by a significant reduction of this activity at $24 \mathrm{~h}$ compared with the other strains and control (untreated milk). Skim milk fermented by L. helveticus strains contained compounds with anti-colon cancer activity at varied levels during fermentation. The activity (19.03-50.98\% growth inhibition) was greatest in the extract obtained after $12 \mathrm{~h}$ of fermentation, which markedly declined (5.4-9.94\%) at the end of fermentation. Lactobacillus helveticus 1315 released compounds into the skim milk supernatant with a greater growth inhibition (50.98\%) on colon cancer HT-29 cell line than the other strains. More importantly, these compounds had no significant inhibition effect on normal, primary colon cells T4056. Whereas these results suggest that milk fermented by L. helveticus strains may release bioactive compounds with important multifunctional properties, the characteristics and activities of these compounds appear highly strain- and fermentation time-dependent.
\end{abstract}

Key words: Lactobacillus helveticus, fermentation, antioxidant, anti-colon cancer

Received July 23, 2015.

Accepted September 24, 2015.

${ }^{1}$ Corresponding author: osaana.donkor@vu.edu.au

\section{INTRODUCTION}

Environmental and dietary changes have been identified as the main causes of noninfectious diseases globally, such as aging-related diseases and cancers (Itano et al., 2012; Johannesdottir et al., 2012; Mogili et al., 2012; Sah et al., 2015). More than 100 types of cancers have been identified, which are common cause of death (Hoskin and Ramamoorthy, 2008). The rate of cancer mortality diagnosed worldwide in 2008 increased by 7 million from 12.7 million in the same year (Jemal et al., 2011). Although some anticancer treatments, such as surgery, chemotherapy, and radiotherapy, have been used with varying success in many types of cancer patients (Pérez-Tomás, 2006), these treatments are expensive (O'Leary et al., 2004) and have deleterious side effects (Chau and Cunningham, 2002), including cardiotoxicities (Curigliano et al., 2010), diarrhea, narrowing of the bowel, and inability of nutrients to be absorbed efficiently (Chau and Cunningham, 2002). The most common side effects include damaging of healthy cells and induction of drug resistance in cancer cells (Kakde et al., 2011). These complications have led to increased interest in approaches using anticancer compounds from natural foods as a treatment alternative to chemotherapy drugs, which can reduce the cost and side effects. Recently, milk proteins and peptides have drawn attention as potential anticarcinogenic drugs through therapeutic or prophylactic effect of carcinogenesis (Sah et al., 2015). These compounds may exert inhibition effect against cancer cells mainly through disrupting cell membrane by pore formation or micellization and caspase-related apoptosis activation (Sah et al., 2015) without a major cytotoxic effect on healthy cells.

Bioactive peptides are inactive in milk proteins and only released by certain proteolytic enzymes, such as digestive enzyme or proteases extracted from plants or microbial sources, including proteolytic enzymes of lactic acid bacteria (LAB), which cleave milk proteins during fermentation (Korhonen and Pihlanto, 2006). Peptides derived from bovine milk proteins are as- 
sociated with significant biological activities, such as anticancer and antioxidant activities (Sah et al., 2015). Under oxidative stress, reactive oxygen species such as superoxide $\left({ }^{\bullet} \mathrm{O}_{2}{ }^{-},{ }^{\bullet} \mathrm{OOH}\right)$, hydroxyl $\left({ }^{\bullet} \mathrm{OH}\right)$, and peroxyl $\left(\mathrm{ROO}^{\bullet}\right)$ radicals are formed (Benbrook, 2005). In the presence of insufficient amounts of antioxidants in human body, free radicals can lead to degenerative or pathological processes, such as aging and cancer, through cellular damage, including oxidation of cellular membrane lipids, proteins, enzymes, and DNA (Benbrook, 2005; Sah et al., 2015). Peptides derived from milk proteins are able to scavenge free radicals in vitro, which may mean that they may enhance endogenous antioxidants in human body to prevent tissue damage through neutralizing free radicals.

Increasing evidence has shown that milk proteinderived cytomodulatory peptides may act as specific signals that can trigger apoptosis of cancer cells while not affecting normal cells (Phelan et al., 2009). The antiproliferative effect of casein-derived peptides on cancer cell lines suggests that they might have a role in the prevention of cancer by blocking hyper proliferation of the epithelium and promote apoptosis (MacDonald et al., 1994; Ganjam et al., 1997). For instance, a peptide derived from bovine lactoferrin (fragment from 17 to 38) exhibited antiproliferative effect against leukemia cell line (HL-60) through apoptosis induction (Roy et al., 2002). Furthermore, bovine lactoferricin, a peptide derived from lactoferrin by pepsin digestion, has antiproliferative effect against neuroblastoma cell lines (Kelly, SK-N-DZ, and IMR-32) through the induction of cleavage of caspase-6, caspase- 7 , and caspase-9 followed by cell death (Eliassen et al., 2006).

Therefore, milk fermented by LAB may contain peptides with antioxidant and antiproliferative properties. The proteolytic enzymes of LAB and their specificity on milk proteins play crucial role in bioactive peptide production (Korhonen, 2009). This mechanism varies among fermented milk microorganisms, which hydrolyze milk proteins at different levels and release different bioactive peptides depending on strain selection (Donkor et al., 2007; Gupta et al., 2009).

Many strains of $L$. helveticus have been extensively used in dairy studies due to their rapid growth in milk, ability to grow under acid stress, and high proteolytic activity accompanied with release of bioactive peptides from milk proteins (Elfahri et al., 2014). Selected $L$. helveticus strains were capable of releasing a variety of bioactive peptides with potentially different physiological functions including inhibition of angiotensinconverting enzyme (ACE) and immunomodulation (Elfahri et al., 2014). However, the release of antioxidant and anti-colon cancer components by these strains during growth in milk has not been fully detailed.
Therefore, understanding the role of different strains of $L$. helveticus in relation to the kinetics of potential antioxidant and anti-colon cancer peptides released from milk proteins and their stability during milk fermentation would be imperative for appropriate strain selection. In the present paper, 4 highly proteolytic strains of L. helveticus, 953, 474, 1188, and 1315, were studied for their ability to release antioxidative and anti-colon cancer compounds from skim milk during fermentation for up to $24 \mathrm{~h}$ at $37^{\circ} \mathrm{C}$.

\section{MATERIALS AND METHODS}

\section{Culture Propagation}

Lactobacillus helveticus ASCC953, L. helveticus ASCC474, L. helveticus ASCC1188, and L. helveticus ASCC1315 were obtained from the Australian Starter Culture Collection (Dairy Innovation Australia, Werribee, Australia). The strains were stored at $-80^{\circ} \mathrm{C}$. Each strain was propagated as reported previously (Elfahri et al., 2014). Briefly, 10-mL aliquots of aseptic de Man, Rogosa, Sharpe broth (Merck KGaA, Darmstadt, Germany) were prepared and inoculated separately with $100 \mu \mathrm{L}$ of each strain followed by incubation at $37^{\circ} \mathrm{C}$ for $24 \mathrm{~h}$. After 2 consecutive transmissions of $24-\mathrm{h}$ incubations, the preinocula cultures were prepared by transferring $1 \%(\mathrm{vol} / \mathrm{vol})$ of activated culture $\left(10^{8}-10^{9}\right.$ $\mathrm{cfu} / \mathrm{mL}$ ) to $10-\mathrm{mL}$ aliquots of reconstituted sterile skim milk (RSM) containing 12\% (wt/wt) total milk solids (Fonterra, Auckland, New Zealand) to reach the initial concentration about $10^{6}$ to $10^{7} \mathrm{cfu} / \mathrm{mL}$ in medium. The last step was to produce food-grade strains in RSM before transferring the culture into milk.

\section{Fermented Milk Sample Preparation}

One liter of RSM (12\% TS) was prepared by adding appropriate amount of skim milk powder (Fonterra) to Milli Q water, followed by stirring for full dispersion and heat treatment at $85^{\circ} \mathrm{C}$ for $30 \mathrm{~min}$. The heat-treated milk was then cooled to approximately $40^{\circ} \mathrm{C}$. The sterile RSM was aseptically inoculated with $1 \%$ (vol/ vol) of each activated strain (approximately $10^{7}$ cells/ $\mathrm{mL}$ ) and incubated at $37^{\circ} \mathrm{C}$ for $24 \mathrm{~h}$ for optimal growth. Samples were taken for analysis at 0-, 4-, 8-, 12-, and 24-h intervals during incubation. The change in $\mathrm{pH}$ during incubation was measured with a $\mathrm{pH}$ meter (model 8417; Hanna Instruments, Singapore, Singapore) at the given time intervals.

Cell population of each $L$. helveticus strain was assessed using sterile bacteriological peptone (vol/vol) and the pour-plate technique (Elfahri et al., 2014). Assessment of samples were performed in triplicate and 
enumerated on de Man, Rogosa, Sharpe-sorbitol agar under anaerobic incubation using anaerobic kits at $37^{\circ} \mathrm{C}$ for $72 \mathrm{~h}$. Plates containing 25 to 250 colonies were enumerated and the colony-forming units per milliliter of the samples were calculated.

\section{Determination of Proteolytic Activity}

The extent of proteolytic activity in milk at $0,4,8$, 12 , and $24 \mathrm{~h}$ of fermentation was measured by assessing release of free amino groups using the o-phthaldialdehyde (OPA) method (Church et al., 1983) and following the procedure reported previously (Elfahri et al., 2014). Briefly, $10 \mathrm{~mL}$ of $1 \%$ (wt/vol) TCA, to precipitate large proteins, was added to $10 \mathrm{~mL}$ of each sample. The mixture was centrifuged (Sorvall RT7 centrifuge, DuPont, Newtown, CT) at 4,000 $\times g$ for $30 \mathrm{~min}$ at $4^{\circ} \mathrm{C}$ and the supernatant was vacuum-filtered using a 0.45- $\mu \mathrm{m}$ filter tip (Schleicher \& Schuell GmbH, Dassel, Germany). The collected suspension $(150 \mu \mathrm{L})$ was then mixed with $3 \mathrm{~mL}$ of OPA reagent and left at room temperature $\left(\sim 20^{\circ} \mathrm{C}\right)$ for $2 \mathrm{~min}$. The absorbance of each mixture was measured at $340 \mathrm{~nm}$ with NovaSpec-II Spectrophotometer (Pharmacia, Cambridge, UK), and proteolytic activity was expressed as the absorbance of OPA derivatives at $340 \mathrm{~nm}$. The relative degree of proteolytic activity of all samples was compared with that of control milk at the start of fermentation.

\section{Preparation of Soluble Extracts}

Each sample of fermented and untreated RSM (200 $\mathrm{mL}$ ) had its $\mathrm{pH}$ adjusted to 4.6 by addition of $2 M$ $\mathrm{HCl}$. The samples were then centrifuged (J2-HS rotor, Beckman Instruments Inc., Palo Alto, CA) at 14,000 × $g$ at $4^{\circ} \mathrm{C}$ for $30 \mathrm{~min}$. The supernatant was filtered separately through a $0.22-\mu \mathrm{m}$ membrane filter (Schleicher \& Schuell GmbH) to avoid microbial contamination. The filtrate was then freeze-dried (Dynavac freeze drier; Dynavac Eng. Pty. Ltd., Melbourne, Australia) and stored at $-80^{\circ} \mathrm{C}$ for further analysis.

\section{Determination of Radical Scavenging Activity}

The 1,1-diphenyl-2-picrylhydrazyl (DPPH) radical was used to determine the free radical scavenging ability of extracted samples (Elfahri et al., 2014). Briefly, $800 \mu \mathrm{L}$ of $0.1 \mathrm{~m} M \mathrm{DPPH}$ dissolved in $95 \%$ methanol were added to $0.2 \mathrm{~mL}$ of each soluble extract in glass test tubes. The solutions were shaken vigorously, sealed with para film, and incubated in the dark at room temperature for $30 \mathrm{~min}$. The methanolic DPPH was used as a blank and methanol was used for the baseline correc- tion. After incubation, the reduction of absorbance was measured at $517 \mathrm{~nm}$ using a UV-Vis spectrophotometer (Biochrom Ltd., Cambridge, UK). All experiments were carried out in triplicate. The radical scavenging activity was expressed as the inhibition percentage and was calculated using the following formula:

$$
\begin{gathered}
\text { Radical scavenging activity }(\%)=[1-(\text { absorbance } \\
\text { of sample/absorbance of blank })] \times 100 .
\end{gathered}
$$

\section{Cell Thawing and Maintenance}

Human colonic epithelial carcinoma cell line (HT29, colorectal adenocarcinoma) was obtained from the American Type Culture Collection (ATCC, Rockville, $\mathrm{MD}$ ), and human primary colon cell line, T4056, was obtained from Applied Biological Material (ABM Inc., Richmond, Canada). To propagate and activate each culture, $1 \mathrm{~mL}$ of HT-29 or T4056 $\left(10^{6} / \mathrm{mL}\right.$ concentration) was quickly thawed and rapidly diluted in $20-\mathrm{mL}$ aliquots of RPMI-1640 growth medium containing $10 \%$ fetal bovine serum (Invitrogen, Waltham, MA), and the cell cultures were pelleted by centrifugation at $200 \times g$ for $5 \mathrm{~min}$ at $20^{\circ} \mathrm{C}$. The pelleted cells were resuspended in $20 \mathrm{~mL}$ of complete growth medium supplemented with $1 \%$ of penicillin-streptomycin and incubated in $75-\mathrm{cm}^{2}$ cell culture flasks for $1 \mathrm{wk}$. The medium was replaced with fresh growth medium every $2 \mathrm{~d}$. Following this step, the aggregated colon cancer and primary colon cells were dissociated by washing with PBS and then replacing medium with $5 \mathrm{~mL}$ of trypsin/EDTA (Gibco, Thermo Fisher Scientific, Waltham, MA) and incubated at $37^{\circ} \mathrm{C}$ for $5 \mathrm{~min}$. The trypsin solution was inactivated by adding $15 \mathrm{~mL}$ of complete growth medium. The trypsinized cell suspension was removed by centrifugation $\left(200 \times g\right.$ for $5 \mathrm{~min}$ at $\left.20^{\circ} \mathrm{C}\right)$ and cells were resuspended with complete medium in a $50-\mathrm{mL}$ falcon tube. The cells were stained using trypan blue at a 1:1 ratio for 3 min before counting via a hemocytometer (Sigma Aldrich, St Louis, MO). Cells were counted on the 4 outer quadrants of the hemocytometer using a light microscope (Olympus CH-2, model CHT, Olympus Optical Co. Ltd., Tokyo, Japan) at $400 \times$ magnification. The diluted cells were divided to 2 portions, one was for passaging into a new flask for continuing propagation $\left(1.0 \times 10^{6} / \mathrm{mL}\right)$ and the other portion $(1.0$ $\left.\times 10^{3} / 100 \mu \mathrm{L}\right)$ was used for antiproliferative assay.

\section{MTS Proliferation Assay}

The MTS [3-(4,5-dimethylthiazol-2-yl)-5-(3carboxymethoxyphenyl)-2-(4-sulfophenyl)-2H-tetrazolium] Assay (CellTiter 96 AQueous One Solution Cell 
Proliferation Assay; Promega, Madison, WI) was performed as described in the manufacturer's instructions. Briefly, cells (HT-29 or T4056) were initially passaged, and counted in a hemocytometer for the purpose of calculating the appropriate seeding. Cells were plated at the concentration of $1.0 \times 10^{3}$ cells per well and the inhibition of cell proliferation was assayed using the MTS assay (CellTiter 96 AQueous One Solution Cell Proliferation Assay, Promega). Briefly, $20 \mu \mathrm{L}$ of soluble extract sample were added to the cells $\left(1.0 \times 10^{3}\right.$ in 80 $\mu \mathrm{L}$ of complete medium). After $72 \mathrm{~h}$ of exposure of the sample to the cells, the MTS reagent $(20 \mu \mathrm{L} / 100 \mu \mathrm{L}$ of medium) was added and incubated for an additional 4 $\mathrm{h}$ under the same conditions. The absorbance of formazan was measured at $495 \mathrm{~nm}$ and unstimulated cells were used as a control. All assays were performed in triplicates and the results expressed as mean values \pm standard error. The percentage of cell inhibition of colon cancer and normal colon cells was calculated (Kim et al., 2000) from a ratio of treatment values compared with controls as follows:

$$
\begin{gathered}
\text { Proliferative inhibition }(\%)= \\
\left(\text { Treatment } \mathrm{A}_{495} / \text { Control } \mathrm{A}_{495}\right) \times 100,
\end{gathered}
$$

where $\mathrm{A}_{495}=$ absorbance at $495 \mathrm{~nm}$.

\section{Statistical Analysis}

All the experiments were carried out in triplicate for each bacterial culture. Results obtained were analyzed as a blocked split plot in time design with 2 main factors: strains and replications as the main plot and time as a subplot. The replications served as a block. The statistical evaluations of the data were performed using the general linear model of SAS (version 6.11; SAS Institute Inc., Cary, NC). Significant differences between treatments were tested by ANOVA followed by a comparison between treatments performed by Fisher's least significant difference method with a level of significance of $P<0.05$.

\section{RESULTS AND DISCUSSION}

The 4 L. helveticus strains (953, 474, 1188, and 1315) selected for our study have been shown to be highly proteolytic mainly due to cell wall proteases (Virtanen et al., 2007; Nielsen et al., 2009; Elfahri et al., 2014) and with metabolic activities leading to the release of several different peptides. The culture performance was assessed by the production of organic acids as the primary metabolites, measured by decline in $\mathrm{pH}$ (Table 1 ). The growth of the selected strains was evaluated by determining viable cell counts (Figure 1), and significantly $(P<0.05)$ increased after $12 \mathrm{~h}$ of fermentation. The bacterial population levelled after $12 \mathrm{~h}$ with exception of L. helveticus 953, which showed slightly decreased counts toward the end of fermentation. Although the growth of L. helveticus 1315 was consistent during the first $4 \mathrm{~h}$ of fermentation, it grew to higher cell densities $(P<0.05)$ than $L$. helveticus 953 , was similar to other strains at the end of fermentation, and was able to continue proliferating under highly acidic conditions, which indicates strain dependence and acid resistance (Elfahri et al., 2014). For appropriate growth performance in milk, a starter culture requires highly developed proteolytic and glycolytic systems capable of providing essential compounds for the culture growth (AA, glucose; Kunji et al., 1996). Whereas glucose is primarily required for meeting energy requirements, provision of AA is needed to support adequate growth rate. These AA are obtained through a complex proteolytic apparatus that starts with a cell wall-bound protease (Elfahri et al., 2014). This enzyme liberates oligopeptides that are taken across the cell wall into the cytoplasm where they are further degraded to simpler peptides and, consequently, AA. It is not clear which enzymes are responsible for liberation of bioactive peptides, but even oligopeptides appear to have a very potent physiological activity (Ashar and Chand, 2004). Apparent bioactivity in water extracts was most likely time-dependent, indicating that some of these peptides may be further degraded resulting in loss or gain of potency (Donkor et al., 2007). In the current study, proteolytic activity of selected L. helveticus strains in pasteurized skim milk was first assessed using the ability of OPA to react with primary amines to form fluorescent moieties. As indicated in Table 1, all strains showed higher $(P<0.05)$ proteolytic activity compared with control. The control sample also contained simpler proteinaceous forms that reacted with OPA, but these levels remained fairly constant as opposed to the fermented samples. The proteolytic activity was highly $(P$ $<0.05)$ strain-dependent, with $L$. helveticus 1315 appearing to be the most proteolytic $(P<0.05)$ at the end of fermentation, which could be related to viability and activity of this strain under the fermentation conditions. In general, this increase indicates formation of peptides based on cultural proteolytic enzyme specificity, with some likely showing different bioactivities (Elfahri et al., 2014). Milk protein-derived bioactive peptides, such as antioxidant and antiproliferation peptides, have been reported to be potential natural alternative to synthetic drugs and complementary to traditional dietary intake (Kannan et al., 2012); however, the mechanism of action is yet to be established. 
Table 1. Decline of $\mathrm{pH}$ and extent of proteolysis as measured using the o-phthaldialdehyde (OPA) method during growth of Lactobacillus helveticus strains in sterile reconstituted skim milk for $24 \mathrm{~h}$ at $37^{\circ} \mathrm{C}^{1}$

\begin{tabular}{llcc}
\hline Incubation time $(\mathrm{h})$ & Strain code & $\mathrm{pH}$ & OPA at $340 \mathrm{~nm}$ \\
\hline 0 & Control & $6.61 \pm 0.01^{\mathrm{A}}$ & $0.31 \pm 0.01^{\mathrm{B}}$ \\
& L1188 & $6.42 \pm 0.03^{\mathrm{B}}$ & $0.52 \pm 0.01^{\mathrm{A}}$ \\
& L1315 & $6.41 \pm 0.02^{\mathrm{B}}$ & $0.48 \pm 0.01^{\mathrm{A}}$ \\
L474 & $6.44 \pm 0.04^{\mathrm{B}}$ & $0.50 \pm 0.02^{\mathrm{A}}$ \\
& L953 & $6.48 \pm 0.06^{\mathrm{B}}$ & $0.33 \pm 0.02^{\mathrm{B}}$ \\
& Control & $6.61 \pm 0.01^{\mathrm{A}}$ & $0.33 \pm 0.01^{\mathrm{E}}$ \\
& L1188 & $6.14 \pm 0.05^{\mathrm{B}}$ & $0.55 \pm 0.01^{\mathrm{C}}$ \\
& L1315 & $6.06 \pm 0.15^{\mathrm{B}}$ & $0.71 \pm 0.01^{\mathrm{A}}$ \\
& L474 & $6.07 \pm 0.05^{\mathrm{B}}$ & $0.58 \pm 0.01^{\mathrm{B}}$ \\
& L953 & $6.29 \pm 0.03^{\mathrm{B}}$ & $0.37 \pm 0.01^{\mathrm{D}}$ \\
& Control & $6.58 \pm 0.01^{\mathrm{A}}$ & $0.34 \pm 0.01^{\mathrm{D}}$ \\
& L1188 & $4.92 \pm 0.18^{\mathrm{B}}$ & $0.65 \pm 0.01^{\mathrm{C}}$ \\
& L1315 & $4.66 \pm 0.36^{\mathrm{B}}$ & $0.97 \pm 0.0^{\mathrm{A}}$ \\
& L474 & $4.50 \pm 0.09^{\mathrm{B}}$ & $0.93 \pm 0.02^{\mathrm{A}}$ \\
& L953 & $4.91 \pm 0.26^{\mathrm{B}}$ & $0.83 \pm 0.02^{\mathrm{B}}$ \\
& Control & $6.54 \pm 0.01^{\mathrm{A}}$ & $0.35 \pm 0.03^{\mathrm{C}}$ \\
& L1188 & $3.85 \pm 0.03^{\mathrm{C}}$ & $0.90 \pm 0.01^{\mathrm{B}}$ \\
& L1315 & $3.77 \pm 0.03^{\mathrm{C}}$ & $1.20 \pm 0.01^{\mathrm{A}}$ \\
& L474 & $3.75 \pm 0.03^{\mathrm{C}}$ & $1.21 \pm 0.01^{\mathrm{A}}$ \\
& L953 & $3.99 \pm 0.05^{\mathrm{B}}$ & $1.21 \pm 0.02^{\mathrm{A}}$ \\
& Control & $6.53 \pm 0.07^{\mathrm{A}}$ & $0.35 \pm 0.02^{\mathrm{C}}$ \\
& L1188 & $3.48 \pm 0.14^{\mathrm{B}}$ & $1.30 \pm 0.01^{\mathrm{B}}$ \\
& L1315 & $3.34 \pm 0.06^{\mathrm{B}}$ & $1.73 \pm 0.02^{\mathrm{A}}$ \\
& L474 & $3.38 \pm 0.06^{\mathrm{B}}$ & $1.51 \pm 0.01^{\mathrm{BA}}$ \\
& L953 & $3.46 \pm 0.1^{\mathrm{B}}$ & $1.52 \pm 0.16^{\mathrm{BA}}$ \\
\hline
\end{tabular}

${ }^{\mathrm{A}-\mathrm{C}}$ Means in the same column at particular incubation time with different uppercase letters are significantly different $(P<0.05)$.

${ }^{1}$ Values are mean of 3 replicates (mean $\pm \mathrm{SE}$ ).

The antioxidant activity of crude peptide extracts was evaluated by measuring the reduction of DPPH radical concentration when it encountered radical scavengers. The free radical scavenging activity in the samples changed significantly $(P<0.05)$ from 0 to 12 $\mathrm{h}$ compared with the control (Figure 2). This change varied among selected $L$. helveticus strains, which might be due to the fact antioxidant capacity is not usually connected with continuing protein hydrolysis or bacteria growth but is likely related to strain selection and proteolytic enzyme specificity (Virtanen et al., 2007). In the current study, peak antioxidant activity was recorded at $12 \mathrm{~h}$ but declined significantly $(P<$ 0.05 ) after $24 \mathrm{~h}$ of fermentation (Figure 2). However, antioxidative peptides have been reported to be hydrolyzed from milk proteins by LAB fermentation after 24 h (Virtanen et al., 2007; Osuntoki and Korie, 2010). Sample extract from RSM fermented with $L$. helveticus 474 showed the highest $(P<0.05)$ antioxidant activity $(6.54 \%$ at $0 \mathrm{~h}$ to $48.01 \%$ at $12 \mathrm{~h})$. Similar trends were observed for L. helveticus 1315 and 1188 (42.98 and $41.34 \%$, respectively) at $12 \mathrm{~h}$ (Figure 2). These results indicate that antioxidant of crude peptide extracts released during fermentation may have ability to neutralize free DPPH radicals either by hydrogen atom or by direct reduction through electron transfer (Sah et al., 2014). These compounds might be pep- tides formed during fermentation by the action of $L$. helveticus proteolytic enzymes. Although many studies determined antioxidant activity from fermented milk in different models and fermented microorganisms (Qian et al., 2011; Sah et al., 2014), the confirmation about a type of enzyme responsible for this activity is still not available (Kilpi et al., 2007). Furthermore, the size and composition of peptides released are connected with certain bioactivity. Histidine-rich peptide isolated from milk fermented by Lactobacillus delbrueckii ssp. bulgaricus IFO13953 showed DPPH radical scavenging activity (Kudoh et al., 2001). Alanine-, Phe-, Gly-, and Pro-rich peptides have also been reported (Hernández et al., 2005; Dryáková et al., 2010; Li et al., 2013); therefore, L. helveticus stains used in our study might be able to produce antioxidant peptides from milk proteins rich with the previously mentioned AA.

The strain-dependent variations of these activities may also be attributed to the production of different bioactive compounds such as peptides, which exhibited different antioxidant properties (Qian et al., 2011). Further hydrolysis of some potential antioxidative components by L. helveticus enzymes could be the reason for the reduction of antioxidant activity after $24 \mathrm{~h}$ of incubation. Conversely, a continuing increase in DPPH radical scavenging activity during $28 \mathrm{~d}$ of probiotic and symbiotic yogurt storage at $4^{\circ} \mathrm{C}$ has been reported 


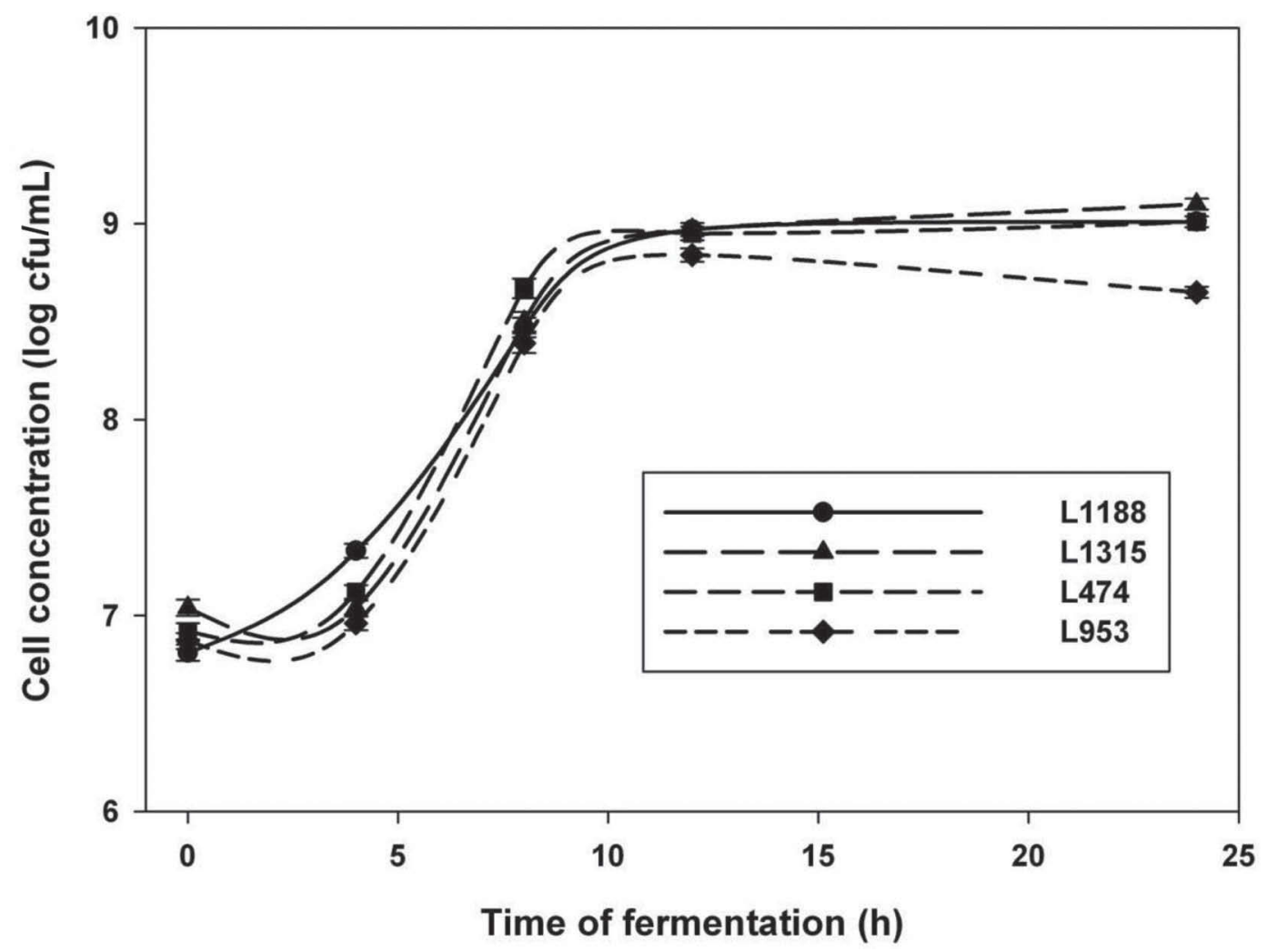

Figure 1. The growth performance of selected Lactobacillus helveticus strains cultivated in $12 \%$ reconstituted skim milk for $24 \mathrm{~h}$ at $37^{\circ} \mathrm{C}$. Error bars represent pooled SEM $(P<0.05)$.

(Madhu et al., 2012). Thus, antioxidant activity in fermented milk might be based on metabolic activity of LAB, which is different among the species and even varies between strains in the same species, and the tolerance of fermented culture to grow under low $\mathrm{pH}$ (Virtanen et al., 2007). The DPPH radical scavenging activity might also be attributed to fermentation progresses $\left(37^{\circ} \mathrm{C}\right.$, final $\mathrm{pH}$ of 3.7 ; Nishino et al., 2000).

Imbalance between free radical formation and antioxidant presence can lead to DNA damage and mutation, which can increase cancer incidence. Thus, antioxidants may play role in prevention or treatment of cancers; they may affect cancer incidence by minimizing reactions that affect cell proliferation induction not only in vitro (Kim et al., 2000), but also in vivo in rats and in human clinical trials (Tsuda et al., 2002; Kozu et al., 2009). The current study evaluated the inhibition effect of crude peptide extracts during fermentation on colon cancer cell (HT-29) proliferation (Figure 3A) and healthy colon cell line (T4056), which are presented in Figure 3B. The cell viability (MTS) assay was used to evaluate in vitro the inhibition of both cell lines (HT-29 and T4056) after treatment with crude peptide extract. Figure $3 \mathrm{~A}$ shows the effect of milk fermented with $L$. helveticus strains on the proliferation of HT-29 colon cancer cell line. All samples showed antiproliferative effects at varied levels compared with the control. The most significant $(P<0.05)$ reduction of HT-29 proliferation was observed with the sample obtained after 12 $\mathrm{h}$ of fermentation. The effect was substantially reduced when the sample obtained at the end of fermentation (24 h) was applied. The percentage of proliferative inhibition after $12 \mathrm{~h}$ of milk fermented by L. helveticus 1315 increased significantly $(P<0.05)$ and was higher than other strains. No significant inhibition of all soluble extracts was detected with the normal T4056 cells (Figure $3 \mathrm{~B})$. It is possible that the reduction in proliferation for HT-29 cell line was due to the increase of concentration of potential bioactive compound in the medium in which certain cell death mechanisms were activated, such as apoptosis (programmed cell death). It has been previously reported that using different concentrations $(25,50,100$, or $200 \mu \mathrm{g} / \mathrm{mL})$ of lactoferricin, a peptide derived from whey lactoferrin protein, has a cytotoxic effect on colon carcinoma cell lines (COLO-35 and HT29) in a dose-dependent manner (Mader et al., 2006). Furthermore, the length of time cells were stimulated may also have a role in decrease of proliferation of can- 
cer cells. Long-term ( 5 wk) of CaCo-2 human colon cancer cells treated with lactoferricin showed a $35 \%$ reduction of cell numbers as compared with control (unstimulated cells; Freiburghaus et al., 2009). Thus, cancer cells with long-term exposure of bioactive compounds may play a role in delaying or reducing cancer progression. The mechanism of this activity is mainly related to cytoplasmic membrane disruption and apoptosis induction (Sah et al., 2015). The hydrophobicity and net charge on peptides with bioactivity may also have crucial role for inducing apoptosis and reducing cancer cell proliferation (Hoskin and Ramamoorthy, 2008; Huang et al., 2011).

We can deduce that $L$. helveticus strains had a statistically significant effect on the release of potential antioxidant and anti-colon cancer compounds during fermentation. Therefore, purification of these bioactive compounds in fermented milk to confirm specific bioactivities is important, as well as the establishment of the relationship between fermentation time and concentrations of these potential bioactive compounds.

In general, bioactive compounds released in our study will likely have multiple physiological properties, which are manifested at different time points during fermentation (Meisel and FitzGerald, 2003). For example, soluble extracts with antioxidative and anti-colon cancer ability appear to be generated continuously and accumulated in the fermented milk up to $12 \mathrm{~h}$ incubation at $37^{\circ} \mathrm{C}$. However, antioxidative and anti-colon cancer compounds produced during culture growth or enzyme activity may or may not exhibit their bioactivities in vivo due to action of gastrointestinal enzymes (Walsh et al., 2004; Roufik et al., 2006). On the other hand, ACE-inhibitory peptides derived from whey $\beta$-LG were able to pass through the gastrointestinal cell monolayers to reach target sites (Vermeirssen et al., 2002).

\section{CONCLUSIONS}

This study reported the use of 4 proteolytic strains of L. helveticus, 953, 474, 1188, and 1315, as potential functional dairy starter cultures capable of releasing a wide range of bioactive compounds from milk. Lactobacillus helveticus strains grew well in skim milk under acidic conditions. Their growth apparently resulted in the release of antioxidative and anti-colon cancer compounds from milk. However, the level of bioactivities appeared to be strain-specific, dependent on fermentation time, temperature, $\mathrm{pH}$ changes, and the concentration of released bioactive compounds in fermented

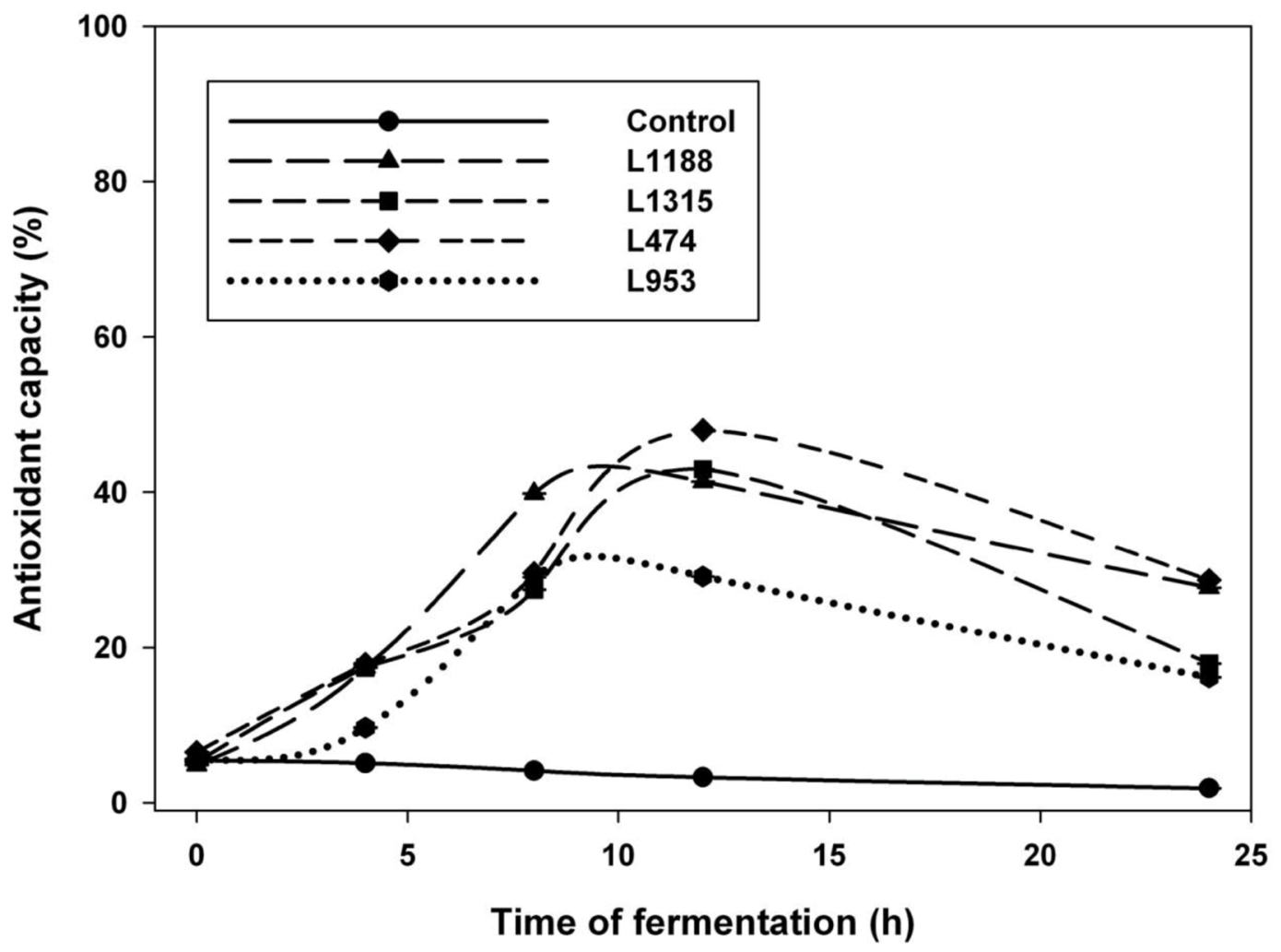

Figure 2. Free radical scavenging activity of peptides in the soluble extract released from skim milk proteins fermented by selected Lactobacillus helveticus strains during $24 \mathrm{~h}$ of incubation at $37^{\circ} \mathrm{C}$. Error bars represent pooled SEM $(P<0.05)$. 

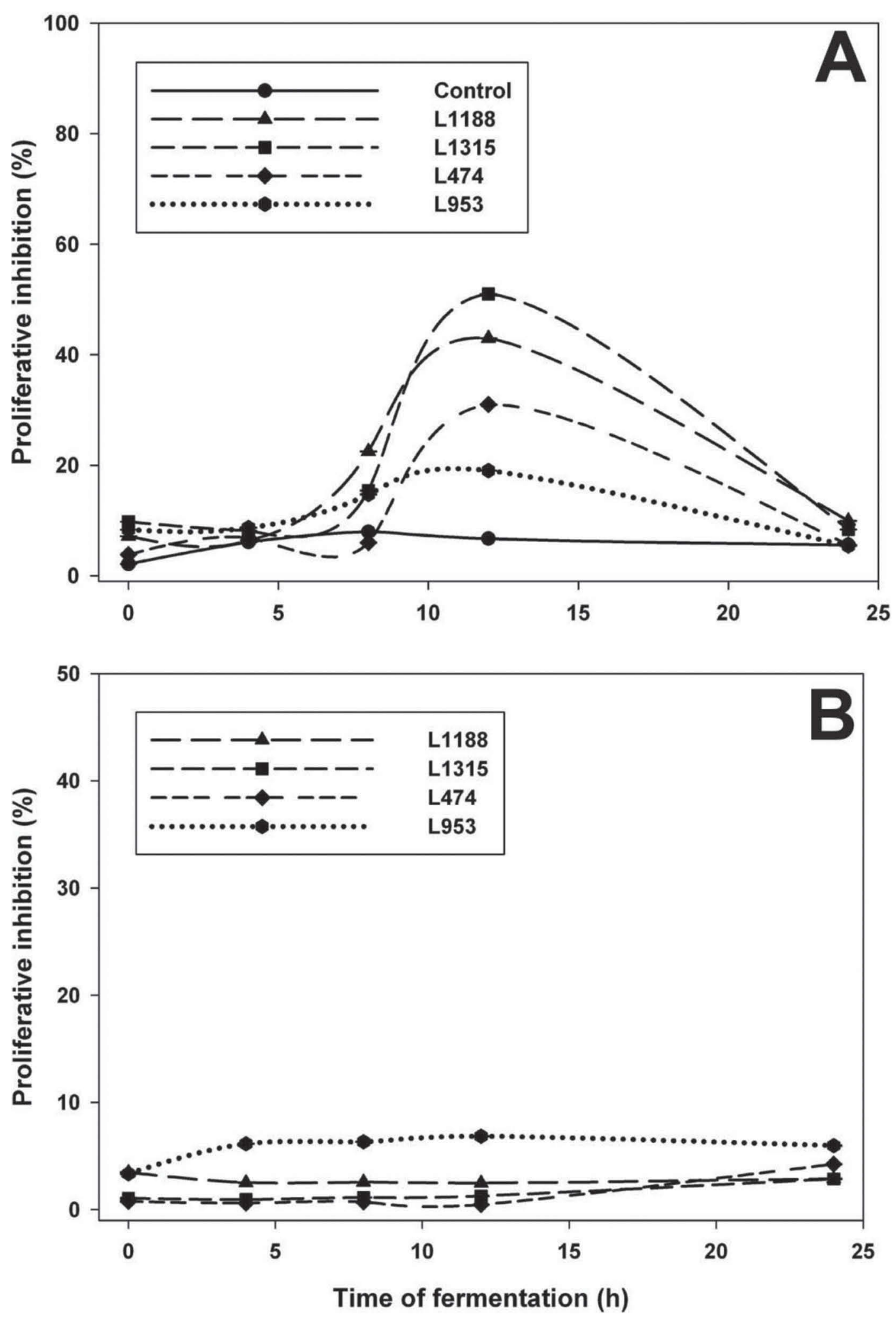

Figure 3. Proliferative inhibition of colon cell lines treated with peptides contained in the soluble extract obtained during fermentation of reconstituted skim milk by Lactobacillus helveticus $1188,1315,474$, and 953. Error bars represent pooled SEM $(P<0.05)$. A $=$ colon cancer cells (HT-29), B = normal colon cells (T4056). 
milk. Lactobacillus helveticus strains have potential to produce bioactive compounds with antioxidative and anticancerogenic activities.

\section{ACKNOWLEDGMENTS}

The authors acknowledge financial support provided by the Libyan Government as a postgraduate scholarship. This study was in part supported by the college of Health and Biomedicine, Victoria University; kind help and support of the technical staff at Werribee campus was greatly appreciated.

\section{REFERENCES}

Ashar, M., and R. Chand. 2004. Fermented milk containing ACEinhibitory peptides reduces blood pressure in middle aged hypertensive subjects. Milchwissenschaft 59:363-366.

Benbrook, C. M. 2005. Elevating Antioxidant Levels in Food Through Organic Farming and Food Processing. The Organic Center, Foster, RI.

Chau, I., and D. Cunningham. 2002. Adjuvant therapy in colon cancer: Current status and future directions. Cancer Treat. Rev. 28:223-236.

Church, F., H. Swaisgood, D. Porter, and G. Catignani. 1983. Spectrophotometric assay using o-phthaldialdehyde for determination of proteolysis in milk and isolated milk proteins. J. Dairy Sci. 66:1219-1227.

Curigliano, G., E. Mayer, H. Burstein, E. Winer, and A. Goldhirsch. 2010. Cardiac toxicity from systemic cancer therapy: A comprehensive review. Prog. Cardiovasc. Dis. 53:94-104.

Donkor, O., A. Henriksson, T. Vasiljevic, and N. Shah. 2007. Proteolytic activity of dairy lactic acid bacteria and probiotics as determinant of growth and in vitro angiotensin-converting enzyme inhibitory activity in fermented milk. Lait 87:21-38.

Dryáková, A., A. Pihlanto, P. Marnila, L. Čurda, and H. Korhonen. 2010. Antioxidant properties of whey protein hydrolysates as measured by three methods. Eur. Food Res. Technol. 230:865-874.

Elfahri, K., O. Donkor, and T. Vasiljevic. 2014. Potential of novel Lactobacillus helveticus strains and their cell wall bound proteases to release physiologically active peptides from milk proteins. Int. Dairy J. 38:37-46.

Eliassen, L. T., G. Berge, A. Leknessund, M. Wikman, I. Lindin, C. Løkke, F. Ponthan, J. Johnsen, B. Sveinbjørnsson, and P. Kogner. 2006. The antimicrobial peptide, lactoferricin B, is cytotoxic to neuroblastoma cells in vitro and inhibits xenograft growth in vivo. Int. J. Cancer 119:493-500.

Freiburghaus, C., B. Janicke, H. Lindmark, M. Oredsson, and A. Paulsson. 2009. Lactoferricin treatment decreases the rate of cell proliferation of a human colon cancer cell line. J. Dairy Sci. 92:2477-2484.

Ganjam, L. S., W. Thornton, R. Marshall, and R. Macdonald. 1997. Antiproliferative effects of yogurt fractions obtained by membrane dialysis on cultured mammalian intestinal cells. J. Dairy Sci. 80:2325-2329.

Gupta, A., B. Mann, R. Kumar, and R. B. Sangwan. 2009. Antioxidant activity of Cheddar cheeses at different stages of ripening. Int. J. Dairy Technol. 62:339-347.

Hernández, B., B. Miralles, L. Amigo, M. Ramos, and I. Recio. 2005. Identification of antioxidant and ACE-inhibitory peptides in fermented milk. J. Sci. Food Agric. 85:1041-1048.

Hoskin, D., and A. Ramamoorthy. 2008. Studies on anticancer activities of antimicrobial peptides. Biochim. Biophys. Acta 1778:357375.

Huang, Y. B., X. Wang, H. Wang, Y. Liu, and Y. Chen. 2011. Studies on mechanism of action of anticancer peptides by modulation of hydrophobicity within a defined structural framework. Mol. Cancer Ther. 10:416-426.

Itano, O., K. Fan, K. Yang, K. Suzuki, F. Quimby, Z. Dong, B. Jin, W. Edelmann, and M. Lipkin. 2012. Effect of caloric intake on western-style diet-induced intestinal tumors in a mouse model for hereditary colon cancer. Nutr. Cancer 64:401-408.

Jemal, A., F. Bray, M. Center, J. Ferlay, E. Ward, and D. Forman. 2011. Global cancer statistics. CA Cancer J. Clin. 61:69-90.

Johannesdottir, S. A., T. Lash, A. Jensen, D. Farkas, and A. Olesen. 2012. Mortality in cancer patients with a history of cutaneous squamous cell carcinoma-A nationwide population-based cohort study. BMC Cancer 12:126.

Kakde, D., D. Jain, V. Shrivastava, R. Kakde, and A. Patil. 2011. Cancer therapeutic-Opportunities, challenges and advances in drug delivery. J. Appl. Pharm. Sci. 2011:1-10.

Kannan, A., N. Hettiarachchy, and M. Marshall. 2012. Food proteins and peptide as bioactive agents. Pages 1-28 in Bioactive Food Proteins and Peptides, Applications in Human Health. CRC Press, Boca Raton, FL.

Kilpi, E., M. Kahala, J. Steele, A. Pihlanto, and V. Joutsjoki. 2007. Angiotensin I-converting enzyme inhibitory activity in milk fermented by wild-type and peptidase-deletion derivatives of Lactobacillus helveticus CNRZ32. Int. Dairy J. 17:976-984.

Kim, S. E., H. Kim, J. Kim, Y. Kang, H. Woo, and H. Lee. 2000. Anticancer activity of hydrophobic peptides from soy proteins. Biofactors 12:151-155.

Korhonen, H., and A. Pihlanto. 2006. Bioactive peptides: Production and functionality. Int. Dairy J. 16:945-960.

Korhonen, H. J. 2009. Bioactive Components in Bovine Milk. WileyBlackwell, Ames, IA.

Kozu, T., G. Inuma, Y. Ohashi, Y. Saito, T. Akasu, D. Saito, D. B. Alexander, M. Iigo, T. Kakizoe, and H. Tsuda. 2009. Effect of orally administered bovine lactoferrin on the growth of adenomatous colorectal polyps in a randomized, placebo-controlled clinical trial. Cancer Prev. Res. (Phila.) 2:975-983.

Kudoh, Y., S. Matsuda, K. Igoshi, and T. Oki. 2001. Antioxidative peptide from milk fermented with Lactobacillus delbrueckii ssp. bulgaricus IFO13953. Jpn. Food Sci. Technol. J. 48:44-50. http:// dx.doi.org/10.3136/nskkk.48.44.

Kunji, E. R., I. Mierau, A. Hagting, B. Poolman, and W. Konings. 1996. The proteolytic systems of lactic acid bacteria. Antonie van Leeuwenhoek 70:187-221.

Li, Z., A. Jiang, T. Yue, J. Wang, Y. Wang, and J. Su. 2013. Purification and identification of five novel antioxidant peptides from goat milk casein hydrolysates. J. Dairy Sci. 96:4242-4251.

MacDonald, R. S., W. Thornton, and R. Marshall. 1994. A cell culture model to identify biologically active peptides generated by bacterial hydrolysis of casein. J. Dairy Sci. 77:1167-1175.

Mader, J. S., D. Smyth, J. Marshall, and D. W. Hoskin. 2006. Bovine lactoferricin inhibits basic fibroblast growth factor-and vascular endothelial growth factor 165-induced angiogenesis by competing for heparin-like binding sites on endothelial cells. Am. J. Pathol. 169:1753-1766.

Madhu, A., N. Amrutha, and S. Prapulla. 2012. Characterization and antioxidant property of probiotic and synbiotic yogurts. Probiotics Antimicrob. Proteins 4:90-97.

Meisel, H., and R. FitzGerald. 2003. Biofunctional peptides from milk proteins: Mineral binding and cytomodulatory effects. Curr. Pharm. Des. 9:1289-1295.

Mogili, S., M. Yousaf, N. Nadaraja, and T. Woodlock. 2012. Management of advanced colon cancer in a community hospital: Impact of age on clinical management and survival. J. Gastrointest. Cancer 43:426-430.

Nielsen, M., T. Martinussen, B. Flambard, K. Sørensen, and J. Otte. 2009. Peptide profiles and angiotensin-I-converting enzyme inhibitory activity of fermented milk products: Effect of bacterial strain, fermentation $\mathrm{pH}$, and storage time. Int. Dairy J. 19:155-165.

Nishino, T., H. Shibahara-Sone, H. Kikuchi-Hayakawa, and F. Ishikawa. 2000. Transit of radical scavenging activity of milk products prepared by Maillard reaction and Lactobacillus casei strain Shi- 
rota fermentation through the hamster intestine. J. Dairy Sci. 83:915-922.

O'Leary, B. A., J. K. Olynyk, A. M. Neville, and C. F. Platell. 2004. Cost-effectiveness of colorectal cancer screening: Comparison of community-based flexible sigmoidoscopy with fecal occult blood testing and colonoscopy. J. Gastroenterol. Hepatol. 19:38-47.

Osuntoki, A., and I. Korie. 2010. Antioxidant activity of whey from milk fermented with Lactobacillus species isolated from Nigerian fermented foods. Food Technol. Biotechnol. 48:505.

Pérez-Tomás, R. 2006. Multidrug resistance: Retrospect and prospects in anti-cancer drug treatment. Curr. Med. Chem. 13:1859-1876.

Phelan, M., A. Aherne, R. FitzGerald, and N. O'Brien. 2009. Caseinderived bioactive peptides: Biological effects, industrial uses, safety aspects and regulatory status. Int. Dairy J. 19:643-654.

Qian, B., M. Xing, L. Cui, Y. Deng, Y. Xu, M. Huang, and S. Zhang. 2011. Antioxidant, antihypertensive, and immunomodulatory activities of peptide fractions from fermented skim milk with Lactobacillus delbrueckii ssp. bulgaricus LB340. J. Dairy Res. 78:72-79.

Roufik, S., S. Gauthier, and S. Turgeon. 2006. In vitro digestibility of bioactive peptides derived from bovine $\beta$-lactoglobulin. Int. Dairy J. 16:294-302.

Roy, M. K., Y. Kuwabara, K. Hara, Y. Watanabe, and Y. Tamai 2002. Peptides from the N-terminal end of bovine lactoferrin in- duce apoptosis in human leukemic (HL-60) cells. J. Dairy Sci 85:2065-2074

Sah, B. N., T. Vasiljevic, S. McKechnie, and O. Donkor. 2014. Effect of probiotics on antioxidant and antimutagenic activities of crude peptide extract from yogurt. Food Chem. 156:264-270.

Sah, B. N. P., T. Vasiljevic, S. McKechnie, and O. N. Donkor. 2015 Identification of anticancer peptides from bovine milk proteins and their potential roles in management of cancer: A critical review. Compr. Rev. Food Sci. Food Saf. 14:123-138.

Tsuda, H., K. Sekine, K. Fujita, and M. Iigo. 2002. Cancer prevention by bovine lactoferrin and underlying mechanisms: A review of experimental and clinical studies. Biochem. Cell Biol. 80:131-136.

Vermeirssen, V., B. Deplancke, K. Tappenden, J. Camp, H. Gaskins, and W. Verstraete. 2002. Intestinal transport of the lactokinin Ala-Leu-Pro-Met-His-Ile-Arg through a Caco-2 Bbe monolayer. J. Pept. Sci. 8:95-100.

Virtanen, T., A. Pihlanto, S. Akkanen, and H. Korhonen. 2007. Development of antioxidant activity in milk whey during fermentation with lactic acid bacteria. J. Appl. Microbiol. 102:106-115.

Walsh, D. J., H. Bernard, B. Murray, J. MacDonald, A. Pentzien, G. Wright, J. Wal, A. Struthers, H. Meisel, and R. FitzGerald. 2004. In vitro generation and stability of the lactokinin $\beta$-lactoglobulin fragment (142-148). J. Dairy Sci. 87:3845-3857. 